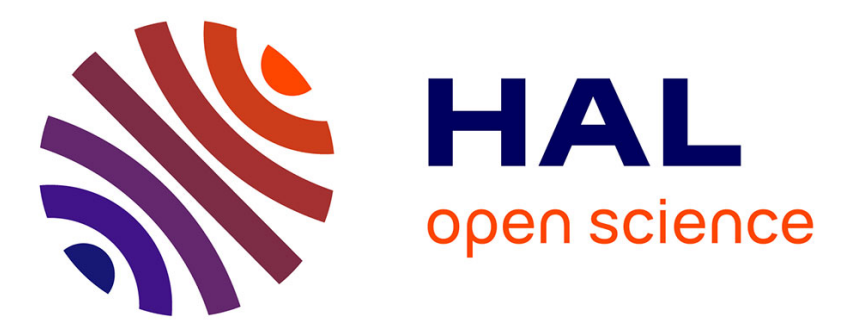

\title{
Adriatic deep water formation during the Holocene: Implication for the reoxygenation of the deep eastern Mediterranean Sea
}

Michel R Fontugne, Martine Paterne, Steve E Calvert, Anne Murat, François

Guichard, Maurice Arnold

\section{To cite this version:}

Michel R Fontugne, Martine Paterne, Steve E Calvert, Anne Murat, François Guichard, et al.. Adriatic deep water formation during the Holocene: Implication for the reoxygenation of the deep eastern Mediterranean Sea. Paleoceanography, 1989, 4 (2), pp.199-206. 10.1029/PA004i002p00199 . hal03543393

\section{HAL Id: hal-03543393 https://hal.science/hal-03543393}

Submitted on 26 Jan 2022

HAL is a multi-disciplinary open access archive for the deposit and dissemination of scientific research documents, whether they are published or not. The documents may come from teaching and research institutions in France or abroad, or from public or private research centers.
L'archive ouverte pluridisciplinaire HAL, est destinée au dépôt et à la diffusion de documents scientifiques de niveau recherche, publiés ou non, émanant des établissements d'enseignement et de recherche français ou étrangers, des laboratoires publics ou privés. 
PALEOCEANOGRAPHY, VOL. 4, NO. 2, PAGES 199-206, APRIL 1989

\section{ADRIATIC DEEP WATER FORMATION DURING THE HOLOCENE: IMPLICATION FOR THE REOXYGENATION OF THE DEEP EASTERN MEDITERRANEAN SEA}

Michel R. Fontugne, ${ }^{1}$ Martine Paterne, ${ }^{1}$

Steve E. Calvert, ${ }^{1,2}$ Anne Murat, ${ }^{3}$

François Guichard, ${ }^{1}$ and Maurice Arnold ${ }^{1}$

\begin{abstract}
Under modern conditions, the reoxygenation of eastern Mediterranean deep water is the result of the formation of dense bottom water in the southern Adriatic Sea. Oxygen isotopic records of planktonic foraminfera used as a paleosalinity tracer show that Po River and/or the alpine glaciers meltwater are not directly responsible of the inhibition of the deep water formation in the Adriatic, during sapropel (S1) formation at 9,000 years B.P.. Sedimentological evidence indicates that fully oxygenated conditions in the deep Adriatic occurred only by $1,650 \pm 100$ years B.P., a long time after the total reoxygenation of the deep eastern Mediterranean. Organic carbon content and isotopic ratio indicate that persistence of a reduced sediment phase until 1,650 years B.P., does not result from increased primary productivity or large input of terrestrial organic matter.
\end{abstract}

\section{INTRODUCTION}

Organic-rich layers occur in Quaternary deep water sedimentary sequences from the Mediterranean Sea

\footnotetext{
1 Centre des Faibles Radioactivités, Laboratoire Centre de la Recherche Scientifique/ Commissariat à l'Energie Atomique, Gif sur Yvette, France.

2 Department of Oceanography, University of British Columbia, Vancouver, British Columbia, Canada.

3 Institut National des Techniques de la Mer, Cherbourg, France.
}

\section{Copyright 1989}

by the American Geophysical Union.

Paper number 88 PA 04246. 0883-8305/89/88PA-04246 $\$ 10.00$
[Bradley, 1938; Olausson, 1961]. These sapropel layers, containing more than $2 \%$ organic carbon, have been attributed either to the stratification of the water column due to a large input of freshwater inhibiting the thermohaline convection [Bradley, 1938; Olausson, 1961; Kullenberg, 1951; Ryan, 1972; Muller, 1973; VergnaudGrazzini et al., 1977; Thunell et al., 1977; RossignolStrick, 1983, 1985], thereby leading to bottom water stagnation, or to a large increase in primary productivity [Calvert, 1983] which increased the flux of organic matter into the deep waters. However, these various hypotheses cannot be checked because of the uncertainties about the origin, beginning, and duration of freshwater input. Furthermore, the ways in which stagnation and consequently the inhibition of bottom water oxygen renewal occurred, have not been well documented. Under modern conditions, the reoxygenation of Mediterranean deep water is the result of the formation of dense bottom water in the southern Adriatic Sea [Pollack, 1951; Lacombe and Tchernia, 1960; Wüst, 1961] which overflows in to the Ionian Sea over the Otrante sill. The formation of Adriatic bottom water presently depends on the wind strength and is directly related to the gradient of atmospheric pressure between northern Europe and the Mediterranean Sea [Zore-Armanda, 1973]. It is very sensitive to small increases in water temperature $\left(0.7^{\circ} \mathrm{C}\right)$ or small decreases in salinity $(0.2 \% \circ)$ which could cause stratification of water masses [Mangini and Schlosser, 1986]. In this context, either an increased flow of freshwater from the Po River and Dalmatian coastal rivers or of meltwater from alpine glaciers may inhibit the formation of deep bottom water. We show here, from a paleohydrological reconstruction of the southern Adriatic Sea and the adjacent Mediterranean Sea, that freshwater input from the northern Adriatic Sea cannot be responsible for a cessation of bottom water formation 
during the last sapropel (S1) formation. The following reoxygenation of the eastern Mediterranean Deep Water was not related to new deep water production in the Otranto basin because sedimentological evidences indicates that fully oxygenated conditions in the deep Adriatic occured only by $1,650 \pm 100$ years B.P..

\section{MATERIALS AND METHODS}

Adriatic Bottom Water is now currently formed during winter in the southern Adriatic Sea due to the cooling of surface water induced by northeast winds (Bora).

However, the formation of such water depends upon the intrusion of saline Levantine Intermediate Water near the Dalmatian coast which increases the density, thereby allowing the water to sink. To determine the impact of freshwater input during the Holocene, we have used variations in the ${ }^{18} \mathrm{O} /{ }^{16} \mathrm{O}$ ratio of planktonic foraminifera as a tracer of the variations of near-surface salinities. As freshwater is depleted in the heavy oxygen isotope compared with seawater, the $\partial^{18} \mathrm{O}$ value of the calcite tests of planktonic foraminifera, such as Globigerinoides ruber (which is dependent upon the isotopic composition of seawater), will record the occurrence of freshwater input and the variation of the salinity gradient [Duplessy, 1982] between the Adriatic Sea and the northern Ionian Sea. However, the $\partial^{18} \mathrm{O}$ of foraminifera also depends on the temperature of seawater in which the foraminifera lived, with a decrease of about $0.25 \% \circ$ for every $1^{\circ} \mathrm{C}$ temperature increase. Fortunately, the surface temperature gradient between the southern Adriatic and Ionian seawater is small (Satmer, Bulletin mensuel de renseignements océanographiques obtenus à partir de mesures satellitaires météorologiques sur la

Méditerranée et l'Atlantique nord-est, Vol. 29-53, published by Direction de la Météorologie Nationale, Boulogne-Billancourt, France, 1986-1987), and we have assumed that it was the same during the whole Holocene period.

We have also estimated the fraction of marine and terrestrial organic matter in the sediments by determining the ${ }^{13} \mathrm{C} /{ }^{12} \mathrm{C}$ ratio of organic matter and applying a simple mixing relationship [Sackett and Thompson, 1963, Fontugne and Duplessy, 1986; Calvert and Fontugne, 1987; Fontugne and Jouanneau, 1987]. The origin of the organic matter within the sapropel or protosapropel layers in the Adriatic Sea is unknown because of the enclosed nature of the basin.

The timing of sapropel S1 deposition and reoxygenation of the bottom water has been determined by the identification of ash layer by geochemical methods which has been correlated with a terrestrial deposit dated by classical radiometric methods [Paterne et al., 1986, 1988] and by ${ }^{14} \mathrm{C}$ measurements of planktonic foraminifera by accelerator mass spectrometry (AMS).

\section{Core Sampling and Sedimentology}

Four cores were selected for this study, one in the south Adriatic Sea (KET 8216, 41 ${ }^{\circ} 31^{\prime} \mathrm{N}, 17^{\circ} 59^{\prime} \mathrm{E}, 1166 \mathrm{~m}$ ) and three in the Ionian Sea (KET 8222, 37 $56^{\prime} \mathrm{N}, 16^{\circ} 53^{\prime} \mathrm{E}$, $1691 \mathrm{~m}$; and RC 9-191, 38 $11^{\prime} \mathrm{N}, 1^{\circ} 02^{\prime} \mathrm{E}, 2345 \mathrm{~m}$; and MD $84658,35^{\circ} 02^{\prime} \mathrm{N}, 17^{\circ} 38^{\prime} \mathrm{E}, 2020 \mathrm{~m}$ ) (Figure 1 ).

Sedimentological and micropaleontological data were obtained only from the Adriatic core KET 8216. This core contains five sedimentary units which are from top to bottom : light brown oxidized mud $(0-8 \mathrm{~cm})$, browngrey mud $(10-30 \mathrm{~cm})$, grey-brown mud $(30-48 \mathrm{~cm})$, sapropelic mud (S1) (48-72 cm), and light grey mud (72$170 \mathrm{~cm}$ ). Dark grey layers occur between 48 and $50 \mathrm{~cm}$, at $55 \mathrm{~cm}$ and between 66 and $72 \mathrm{~cm}$. Cores KET 8222 and RC 9-191 show the same sequence, the sapropel (S1) being divided in two parts; in core MD 84658 it appears as a single level because of the very low sedimentation rate in this core [Murat and Got, 1987]. The stratigraphy of core RC 9-191 has been published by Ryan [1972]; however, some discordance may appear between our depth scale and that of Ryan due to dessication of the core since collection. Nevertheless, the sedimentary sequences observed in cores KET 8222 and MD 84658 (grey-mud-sapropel-oxidized level just above the sapropel) are in good agreement with those observed throughout the eastern Mediterranean Sea [Murat, 1984; Murat and Got, 1987].

\section{Analytical Procedure}

Samples of Globigerinoides ruber were selected every $10 \mathrm{~cm}$ (or every 2 to $3 \mathrm{~cm}$ within the sapropel), and the $\partial^{18} \mathrm{O}$ values were determined by mass spectrometry

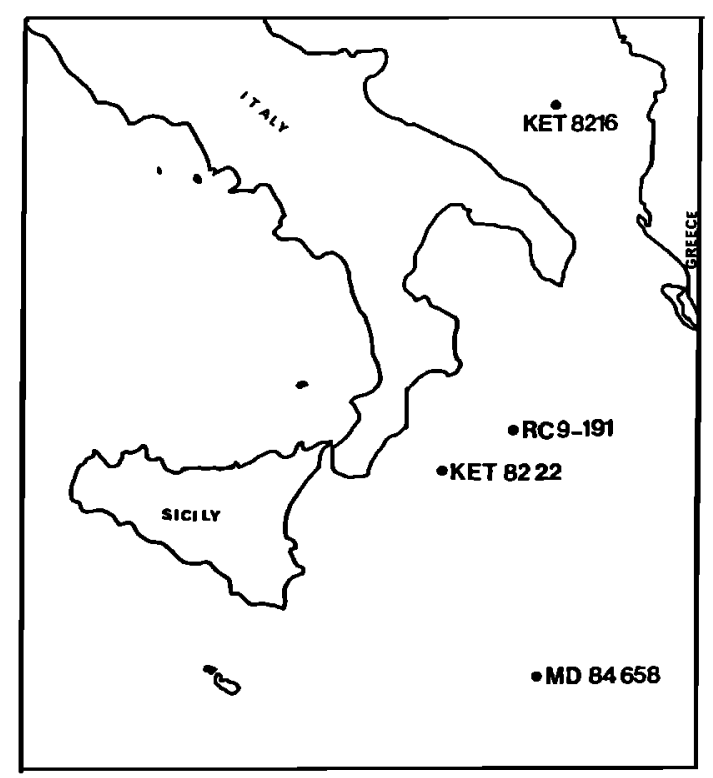

Fig. 1. Core locations. 
following the procedure described by Duplessy [1978]. Organic carbon contents were determined by combustion under oxygen flow and by measuring the evolved $\mathrm{CO}_{2}$ with a Strolheim-Coulomat 702 carbon analyzer, and the carbon isotopic composition of organic matter was determined following the techniques described by Fontugne and Duplessy [1981]. Results of carbon and oxygen isotopic analyses (Table 1) are expressed versus PDB, in per mil, following the conventional fashion as $\partial$ values. AMS radiocarbon dating was performed on mixed planktonic foraminifera when G. ruber was not sufficiently abundant, following the method described by Arnold et al. [1987].

\section{RESULTS AND DISCUSSION}

\section{Stratigraphy}

The stratigraphy of the cores was determined from the $\partial^{18} \mathrm{O}$ variations of Globigerinoides ruber, tephrochronology, and ${ }^{14} \mathrm{C}$ AMS dating. The time scale is reported in Table 2 for each core. All four cores show the same features, similar to those observed in the open ocean, and they demonstrate a complete oxygen isotopic record extending at least to stage 2 as defined by Emiliani [1955]. Core to core correlations were made from the $\partial^{18} \mathrm{O}$ peaks according to the time scale defined by Bard et al. [1987] for the deglaciation period in the North Atlantic Ocean. The 2180 variations are represented versus time in Figure 2; the beginning of the sapropel S1 event is assumed to be synchronous for the four cores.

\section{Origin of the Organic Matter in Core KET 8216}

The proportion of marine and terrestrial organic matter in core KET 8216 has been estimated assuming a value of $-27 \%$ (the modal value of $\mathrm{C} 3$ plants of temperate zone [Dienes, 1980]) which characterizes the terrestrial end member, and $-21 \%$ is typical of the marine plankton [Sackett et al., 1965; Fontugne, 1983; Descolas-Gros and Fontugne, 1985; M. R. Fontugne and S. E. Calvert, unpuplished manuscript, 1989].

Figure 3 and Table 1 show that the sapropelic horizon contains between 0.7 and $1.1 \%$ organic carbon, whereas the other sediments have low amounts $(0.2-0.3 \%)$. From the $\partial^{13} \mathrm{C}$ values, terrestrial organic matter constitutes less than $10 \%$ of the total during the terminal Holocene. During the sapropelic event, however, the terrestrial input increased sharply, varying between 30 and $50 \%$; it remains stable around $30 \%$ between 10,000 and 15,000 years B.P.. The glacial period records a high contribution (reaching $50 \%$ ) except that low values occur just before the first phase of the deglaciation (Termination la). The rather low carbon content during the sapropelic phase together with a low
TABLE 1a. Carbon Isotopic Composition and Content of Organic Matter Versus Depth in Core KET 8216

\begin{tabular}{|c|c|c|}
\hline Depth, cm & Organic carbon \% & Organic carbon $\partial^{13} \mathrm{C}$ \\
\hline 3 & 0.30 & -21.08 \\
\hline 13 & 0.29 & -21.49 \\
\hline 23 & 0.26 & -21.87 \\
\hline 33 & 0.24 & -21.56 \\
\hline 43 & 0.33 & -22.36 \\
\hline 53 & 0.70 & -24.30 \\
\hline 54 & 0.64 & \\
\hline 58 & 0.60 & \\
\hline 61 & 0.67 & \\
\hline 63 & 0.72 & \\
\hline 64 & 0.95 & -23.30 \\
\hline 68 & 1.10 & \\
\hline 73 & 0.36 & -23.62 \\
\hline 83 & 0.33 & -22.71 \\
\hline 93 & 0,25 & $-23,33$ \\
\hline 103 & 0.33 & -23.03 \\
\hline 113 & 0.33 & -22.94 \\
\hline 123 & 0.23 & -23.03 \\
\hline 133 & 0.26 & -23.08 \\
\hline 143 & 0.24 & -23.15 \\
\hline 153 & 0.23 & -22.94 \\
\hline 163 & 0.22 & -22.31 \\
\hline 173 & 0.19 & -22.63 \\
\hline 183 & 0.26 & -23.07 \\
\hline 193 & 0.28 & -23.06 \\
\hline 203 & 0.18 & -23.52 \\
\hline 213 & 0.08 & -23.81 \\
\hline
\end{tabular}

marine organic matter contribution suggests that primary productivity was probably not responsible for sapropel S1 formation in the Otrante basin.

\section{Sapropel S1 Formation and the Origin of the Stagnation}

During the sapropelic phase the $\partial^{18} \mathrm{O}$ values of $\mathrm{G}$. ruber reach values as low as $-0.2 \% \circ$ in the Otrante basin and -0.80 to $-0.85 \%$ in the Ionian Sea core. G. ruber mainly lives during summer and autumn in the central Mediterranean Sea and the Adriatic [Emiliani, 1969; Vergnaud-Grazzini et al., 1986] and consequently may record the input of freshwater mainly from the Po River to the Adriatic Sea. Similarly, cores RC 9-191 and KET 8222 are located near the Calabrian and Sicilian coasts where the surface water outflow from the Adriatic occurs [Barale et al., 1984]. Consequently, $\partial 18 \mathrm{O}$ values in these cores will be representative of the input and/or the output of freshwater in the Adriatic Sea. Figure 2 shows that Termination I in the Adriatic Sea occurs 
TABLE $1 \mathrm{~b}$. Values of $\partial^{18} \mathrm{O}$ of Globigerinoides ruber Versus Depth in Cores KET 8216, KET 8222, MD 84658 and RC 9-191

\begin{tabular}{ll}
\hline Depth, cm & $\partial^{18} \mathrm{O}$ \\
\hline
\end{tabular}

Core KET 8216

0.79

10

20

30

40

50

52

57

60

63

67

70

80

90

100

110

120

129

140

150

170

Core KET 8222

10
20
30
40
50
60
70
80
90
100
110
120
130
140
150
160

2
6
9
14
17
22
28
36

Core MD 84658
TABLE 1b. (continued)

\begin{tabular}{|c|c|}
\hline Depth, cm & $\partial^{18}$ \\
\hline \multicolumn{2}{|c|}{ Core MD 84658 (continued) } \\
\hline 42 & 2.40 \\
\hline \multicolumn{2}{|c|}{ Core RC 9-191 } \\
\hline 15 & 0.72 \\
\hline 20 & 0.71 \\
\hline 30 & 0.60 \\
\hline 43 & 0.32 \\
\hline 50 & -0.22 \\
\hline 51 & -0.59 \\
\hline 55 & -0.69 \\
\hline 56 & 0.05 \\
\hline 62 & -0.16 \\
\hline 64 & 0.22 \\
\hline 68 & -0.54 \\
\hline 74 & -0.86 \\
\hline 84 & 0.99 \\
\hline 100 & 1.63 \\
\hline 113 & 2.70 \\
\hline 128 & 2.78 \\
\hline 136 & 3.16 \\
\hline 145 & 3.13 \\
\hline 156 & 3.09 \\
\hline 164 & 2.93 \\
\hline
\end{tabular}

following the two steps found in the North Atlantic [Duplessy et al., 1981]. Within core KET 8216, the $\partial^{18} \mathrm{O}$ values during Termination $\mathrm{Ib}$ and during the sapropel phase are markedly higher than those of the Ionian Sea cores which exhibit rather constant values from north to south. During the terminal Holocene and the glacial maximum, no $\partial^{18} \mathrm{O}$ gradient occurs between the southern Adriatic Sea and the Ionian Sea. If we assume that, at the end of Termination I, during the sapropel S1 formation, the sea surface temperature gradient during summer was the same as today (about $1^{\circ} \mathrm{C}$ ), the observed gradient in $\partial^{18} \mathrm{O}$ values shows that there was no large input of freshwater or meltwater from the Po River or coastal rivers of the Dalmatian or Italian coasts. This eliminates the Po River as a significant source of low-density water which could lead to vertical density stratification. However, the low $\partial^{18} \mathrm{O}$ values show that somewhat less saline water was present in the Adriatic at this time. The decrease observed since the beginning of the sapropel would correspond to a 4.4 ${ }^{\circ} \mathrm{C}$ decrease of sea surface temperature since the end of Termination $\mathrm{Ib}$ which is not reflected in faunal changes. Hence, these changes are assumed to be due to reduced salinity confirming the stagnation and the slackening of 
TABLE 2. Tephra and ${ }^{14} \mathrm{C}$ AMS chronology for cores KET 8216, KET 8222, MD 84658 and RC 9-191

\begin{tabular}{rcccc}
\hline Depth, cm & $\begin{array}{c}\text { Estimated } \\
\text { Age kyr B.P. }\end{array}$ & $\begin{array}{c}\text { 14C AMS } \\
\text { Age kyr B.P. }\end{array}$ & $\begin{array}{c}\text { Geochemical } \\
\text { Grouping }\end{array}$ & Correlation \\
\hline 10 & 1.50 & $1.65 \pm 0.10$ & TLP & Pollena eruption 472AD \\
11 & & $4.40 \pm 0.15$ & & \\
32 & & $6.27 \pm 0.11$ & $\mathrm{R}$ & Rhyolite Eolian island E-1 \\
49 & 7.00 & $8.61 \pm 0.11$ & & \\
74 & & $9.38 \pm 0.14$ & & Tuff de Agnano \\
73 & & $9.99 \pm 0.16$ & T(B) & Napolitan yellow tuff \\
89 & & & & \\
90 & 9.76 & $13.05 \pm 0.15$ & & \\
117 & 12.30 & $13.78 \pm 0.18$ & & \\
145 & & $16.70 \pm 0.30$ & & \\
169 & & & &
\end{tabular}

Core KET 8222

10-17 Sapropel S1a

34-55 Sapropel S1b

Core RC 9-191

$\begin{array}{rrr}63 & 7.00 & \\ 0-75 & \text { Sapropel } & \\ 8-10 & \text { Sapropel } & \text { Core MD } 84658\end{array}$

Abbreviations are defined as follows: TLP is tephrite-leucite-phonolite series; T(B) is trachyte; and R is ryolite.)

the Adriatic bottom water formation in the Otrante basin.

Time Scale for the Reoxygenation of the Bottom Adriatic Sea

The sediment sequences in the eastern Mediterranean and in the Adriatic Sea are somewhat different. The sapropel S1 is not clearly marked in the Adriatic, and the transition above the sapropel to the oxidized level is gradual, while in the eastern Mediterranean the sapropels are clearly delineated and the transition to the oxidized sediment above is very abrupt (M. Amold, unpublished data, 1989). The sapropelic phase is not well marked within core KET 8216 due to the relatively low carbon content $(0.7$ to $1.1 \%)$, while in the Ionian and Levantin basin cores the organic carbon content exceeds $2 \%$ [Murat, 1984]. The reduced phase between 10 and 48 cm cannot result from increased productivity because of the low sediment organic carbon content $(0.08$ to $0.2 \%)$.
On the other hand the $\partial^{13} \mathrm{C}$ values of the organic matter show a marine fingerprint, thereby excluding large amounts of terrestrial organic material. The occurrence of the oxidized level $40 \mathrm{~cm}$ above the sapropelic phase in core KET 8216 indicates that full reoxygenation of the deep bottom water in the Otrante basin occurred at $1,650 \pm 100$ years B.P., more than 4,000 years after the end of the sapropelic phase. This indicates that the production of Adriatic bottom water, during this period, was weak. This observation is also supported by the benthic faunal record; the genus Uvigerina, which lives in oxygenated water, occurs in large abundance only in the terminal oxidized level. Its occurrence follows an increasing abundance of Hoeglandina elegans (10-40 $\mathrm{cm}$ ) above the sapropel which is followed by the reappearance of benthic fauna at $40 \mathrm{~cm}$. The preservation of pollen abundance also supports the hypothesis of progressive reoxygenation; the pollen number decreases regularly from the sapropel to the top of the core and parallels the increase in oxidation-proof pollen such as spores (M. Rossignol-Strick and N. 


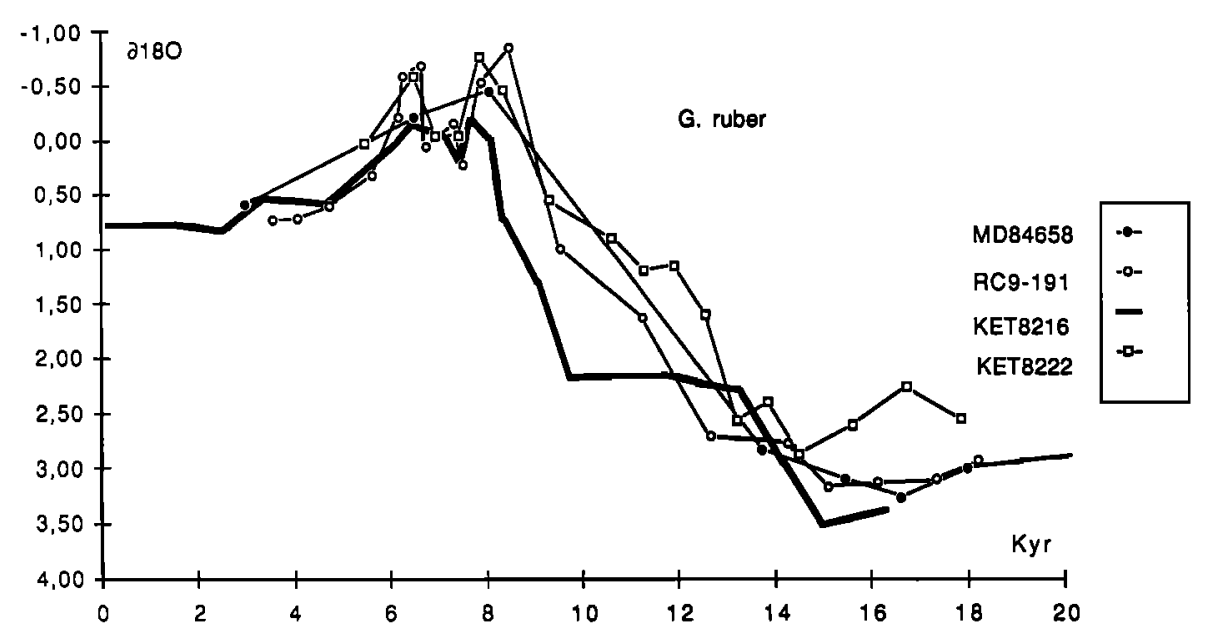

Fig. 2. Variations of $218 \mathrm{O}$ values of Globigerinoides ruber versus time in the cores KET 8216, KET 8222, MD 84658 and RC 9-191.

Planchais, unpublished manuscript, 1989). The sapropel S1 level over the whole eastern Mediterranean Sea is followed directly by a light brown oxidized sediment, suggesting a complete and abrupt reoxygenation of the Mediterranean deep waters [Murat and Got, 1987]. This is in contrast to the progressive reoxygenation of the southern Adriatic Sea which is now the location of the formation of deep water responsible for the oxygenation of the whole eastern Mediterranean. Such observations agree with those of Jorissen et al., [1988] on benthic foraminifera distributions and paleoproductivity which show major changes in surface circulation in the northern Adriatic Sea at about 2,000 years B.P.. The whole set of observations is consistent with the deduced difference in the time of bottom water renewal in the deep eastern Mediterranean and Adriatic seas and indicates at the same time that another source of deep water formation (probably the southern Aegean Sea) was active in the Mediterranean Sea, suggesting a time transgressive reoxygenation of the eastern basins.

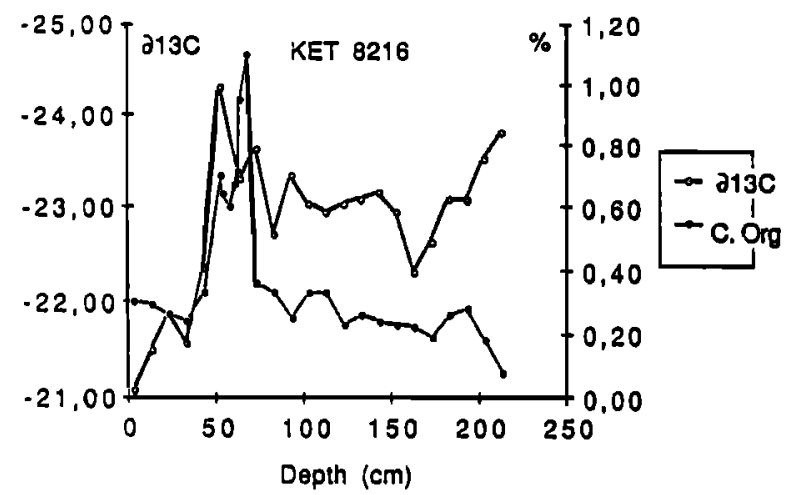

Fig. 3. Variations of organic carbon content and isotopic composition of organic matter versus depth in core KET 8216.
Important changes in the deep ocean water circulation have thus even occurred during the Holocene period.

Acknowledgements. Thanks are due to J. C. Duplessy and J. Palais and for encouragement and helpful discussions. We thank L. Labeyrie for providing facilities for the isotopic analyses, $\mathrm{H}$. Leclaire for micropaleontological studies and B. Lecoat, J. Antignac, A. Vigot for technical assistance and E. Kaltenacker and P. Maurice for ${ }^{14} \mathrm{C}$ AMS dating. This study was supported by the Programme Interdisciplinaire de Recherche pour la Surveillance des Eruptions Volcaniques (PIRPSEV), Commissariat à l'Energie Atomique (CEA) and Centre National de la Recherche Scientifique (CNRS). Cruise ETNA 82 of the French $\mathrm{R} / \mathrm{V}$ Le Suroit was supported by Centre National pour l'Exploitation de l'Océan (CNEXO). Cruise NOEMARMED 84 of the R/V Marion Dufresne was supported by Terres Australes et Antarctiques Françaises (TAAF). The participation of S.E.C in this study was supported by Natural Sciences and Engineering Research Council of Canada (NSERC) and CEA/CNRS. Centre des Faibles Radioactivités (CFR) contribution 1000.

\section{REFERENCES}

Arnold, M., E. Bard, P. Maurice, and J. C. Duplessy, ${ }^{14} \mathrm{C}$ dating with the Gif-sur-Yvette tandetron accelerator: status report, Nuclear Instruments and Methods in Physics Research, SectB, 29, 120-123, 1987

Barale, V., P. Malanotte-Rizzoli, and M. C. Hendershott, Remotely sensing the surface dynamic of the Adriatic Sea, Deep Sea Res., 31, 1433-1459, 1984.

Bard, E., M. Arnold, P. Maurice, J. Duprat, J. Moyes, and J. C. Duplessy, Retreat of the North Atlantic polar front during the last deglaciation determined by ${ }^{14} \mathrm{C}$ 
accelerator mass spectrometry, Nature, 328, 791-794, 1987.

Bradley, W. H., Mediterranean sediments and Pleistocene sea levels, Science, 88, 376-379, 1938.

Calvert, S. E., Geochemistry of Pleistocene sapropel and associated sediment from the eastern Mediterranean, Oceanol. Acta, 6, 255-267, 1983.

Calvert, S. E., and M. R. Fontugne, Stable carbon isotopic evidence for the marine origin of the organic matter in the Holocene Black Sea sapropel, Chem. Geol., Isot. Geosci. Sect., 66, 315-322, 1987.

Deines, P., The isotopic composition of reduced organic carbon, in Handbook of Environmental Isotope Geochemistry, Vol. 1, The Terrestrial environment, edited by P. Fritz and J. C. Fontes, Pp. 329-406, Elsevier, Amsterdam, 1980.

Descolas-Gros, C., and M. R. Fontugne, Carbon fixation in marine phytoplankton: Carboxylase activities and stable carbon isotope ratio; physiological and paleoclimatological aspects, Mar. Biol., 87, 1-6, 1985.

Duplessy, J. C., Isotope studies, in Climatic Change, edited by J. Gribbins, Pp. 46-67, Cambridge Univ. Press, London, 1978.

Duplessy, J. C., Glacial to interglacial contrast in the northern Indian Ocean, Nature, 295, 494-498, 1982.

Duplessy, J.C., G. Delibrias, J. L. Turon, C. Pujol, and J. Duprat, Deglacial warming of the northeastern Atlantic Ocean: Correlation with the paleoclimatic evolution of the European continent,Palaeogeogr. Palaeoclimatol. Palaeoecol, 35, 121-144, 1981.

Emiliani, C., Pleistocene temperatures, J . Geol., 63, 538578, 1955.

Emiliani, C., A new paleontology. Micropaleontology, 15, 265-300, 1969.

Fairbridge, R. W., Quaternary sedimentation in the Mediterranean region controlled by tectonics, paleoclimate and sea level, in The Mediterranean Sea edited by D. J. Stanley, Pp. 99-114, Dowden, Hutchinson and Ross, Stroudsberg, Pa., 1972.

Fontugne M. R., Les isotopes stables du carbone organique dans l'océan: Applications à la paléoclimatologie, thesis, 224pp., Univ. of Paris-Sud, Orsay, 1983.

Fontugne M. R., and J. C. Duplessy, Organic carbon isotopic fractionation by marine plankton in the temperature range -1 to $31^{\circ} \mathrm{C}$, Oceanol. Acta, 4, 85-90, 1981.

Fontugne M. R., and J. C. Duplessy, Variations of the monsoon regime during the upper Quaternary: Evidence from carbon isotopic record of organic matter in the North Indian Ocean sediment core, Palaeogeogr. Palaeoclimatol. Palaeoecol., 56, 69-88, 1986.

Fontugne M. R., and J. M. Jouanneau, Modulation of the particulate organic carbon flux to the ocean by a macro tidal estuary: evidence from measurements of carbon isotopes in organic matter from the Gironde estuary, Estuarine Coastal Shelf Sci., 24, 377-387, 1987.

Jorissen, F.J., K. Van Der Borg, C. M. Houston, W. L. M. Jannissen, and A. F. M. De Jong, ${ }^{14} \mathrm{C}$ dates as a clue to the Holocene history of the Adriatic Sea, paper presented at 13th International Radiocarbon Conference held in Dubrovnik, June 20-25, Abstracts, pp. 110, edited by Rudjer Boskovic Inst., Zagreb, Yugoslavia, 1988.

Kullenberg, B., On the salinity of the water contained in marine sediments, Medd. Oceanogr. Inst. Goteborg 21, 1-38, 1951.

Lacombe, H., and P. Tchernia, Quelques traits généraux de l'hydrologie Méditerranéenne, Cahier Océanogr., 8, 527-547, 1960.

Mangini, A., and P. Schlosser, The formation of eastern Mediterranean sapropels, Mar. Geol., 72, 115-124, 1986.

Muller, C., Calcareous nannoplankton assemblage of Pleistocene-Recent sediments of the Mediterranean Sea, Bull. Geol. Soc. Greece, 10, 133-144, 1973.

Murat A., Séquences et paléoenvironnements marins quaternaires: Une marge active: L'arc hellénique oriental, thesis, 220pp., Univ. of Perpignan, Perpignan, 1984.

Murat, A., and H. Got, Middle and late Quaternary depositional sequences and cycles in the eastern Mediterranean. Sedimentology, 34, 885-899, 1987.

Olausson, E., Studies of deep sea cores, Rep. Swed. Deep Sea Exped., 1947-1948, 8 (4), 353-391, 1961.

Paterne, M., F. Guichard, J. Labeyrie, P. Y. Gillot, and J. C. Duplessy, Tyrrhenian Sea tephrachronology of the oxygen isotope record for the past 60,000 years, Mar. Geol., 72, 259-285, 1986.

Paterne, M., F. Guichard, and J. Labeyrie, Explosive activity of the south Italian volcanoes during the past 80,000 years as determined by marine tephrochronology, J. Volcanol. Geotherm. Res., 34, 153 172, 1988.

Pollack, M. J., The source of the deep water of the eastern Mediterranean sea, J. Mar. Res., 10, 128-152, 1951.

Rossignol-Strick, M., African monsoons, an immediate climate response to orbital insolation, Nature, 295, 105-110, 1983.

Rossignol-Strick, M., Mediterranean quaternary sapropels, an intermediate response of the African monsoon to variation of insolation, Palaeogeogr. Palaeoclimatol. Palaeoecol., 49, 237-263, 1985.

Ryan, W. B. F., Stratigraphy of the late Quaternary sediments in the eastern Mediterranean, in The Mediterranean Sea, edited by D. J. Stanley, pp. 149169, Dowden, Hutchinson and Ross, Stroudsberg, Pa., 1972.

Sackett, W.M., and R. R. Thompson, Isotopic organic carbon composition of recent continental derived clastic sediment of eastern Gulf of Mexico, Am. Assoc. Pet. Geol. Bull., 47, 525-531, 1963.

Sackett, W.M., W. R. Eckelmann, M. L. Bender, and A. W. H. Bé, Temperature dependance of carbon isotopes in marine plankton and sediments, Science, 148, 235, 1965.

Sutherland, H.E., S. E. Calvert and R. J. Morris, Geochemical studies of the recent sapropel and associated sediment from the Hellenic outer ridge, 
eastern Mediterranean Sea. I, mineralogy and chemical composition, Mar. Geol., 56, 79-92, 1984.

Thunell, R. C., D. F. Williams, and J. P. Kennett, Late quaternary paleoclimatology, stratigraphy and sapropel history in eastern Mediterranean deep sea sediments, Mar. Micropaleontol., 2, 371-388, 1977.

Vergnaud-Grazzini, C., W. B. F. Ryan, and M. B. Cita, Stable isotopic fractionation, climate change and episodic stagnation in the eastern Mediterranean during the late Quaternary, Marine Micropaleontol., 2, 353-370, 1977.

Vergnaud-Grazzini, C., M. Devaux, and J. Znaidi, Stable isotope "anomalies" in Mediterranean Pleistocene records, Mar. Micropaleontol., 10, 35-69, 1986.

Wüst, G., On the vertical circulation of the Mediterranean Sea, J. Geophys. Res., 66, 3261-3271, 1961.

Zore-Armanda, M., Formation of the Mediterranean deep sea water in the Adriatic, in Processus de formation des eaux océaniques profondes, 127-133, Colloque Int. CNRS 215, edited by CNRS, Paris, 1973.

M.R. Fontugne, M. Paterne, F. Guichard and M. Arnold Centre des Faibles Radioactivités,

Laboratoire mixte CNRS/CEA, Domaine du CNRS, 91198 Gif sur Yvette Cedex, France.

S. E. Calvert, Department of Oceanography, 6270 University Boulevard, University of British Columbia, Vancouver BC, Canada V6T 1W5.

A. Murat, Institut National des Techniques de la Mer, BP324, 50103 Cherbourg Cedex, France.

(Received September 9, 1988; revised December 7, 1988; accepted December 12,1988.) 